\title{
THE REGULATION OF MARITAL REGISTRATION IN INDONESIA AND MUSLIM COUNTRIES
}

\author{
NUR AZIZAH \\ IAIN Manado, North Sulawesi \\ E-Mail: Nurazizahhutagalungdo@gmail.com \\ DOI: $h$ ttp://dx.doi.org/10.24952/fitrah.v5i2.1927

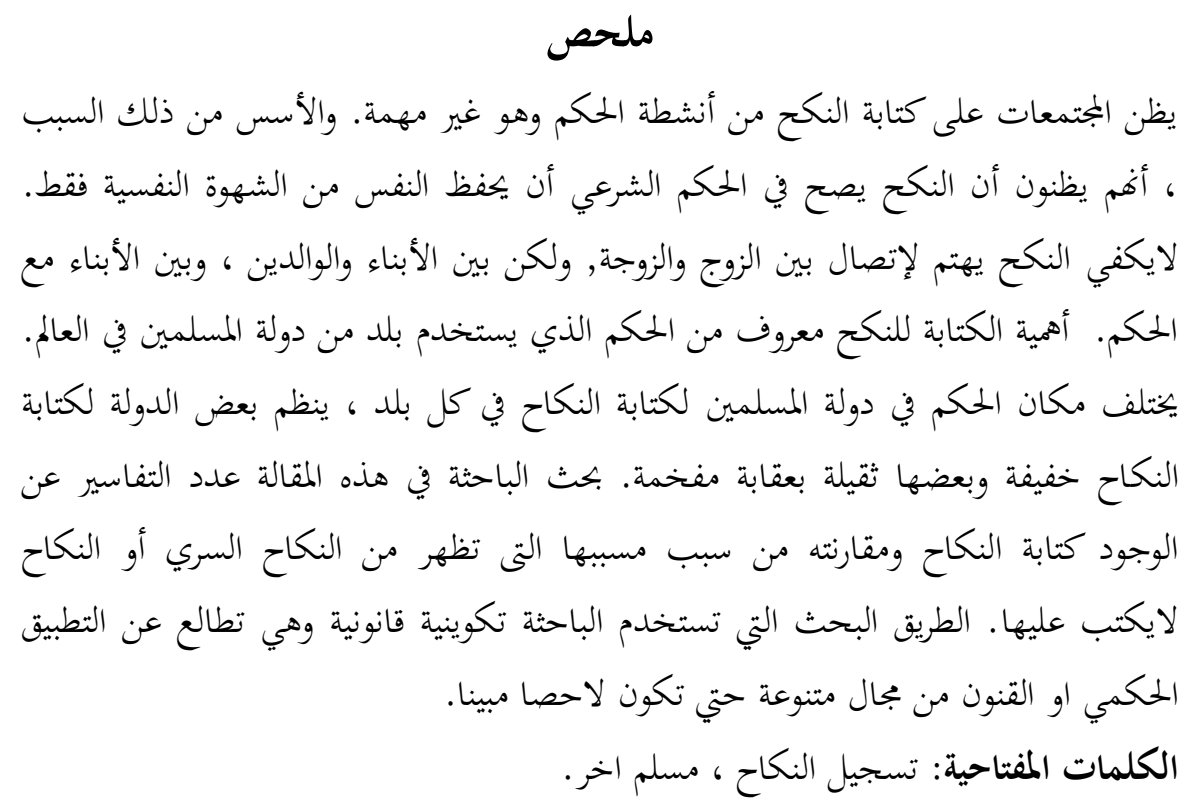

Abstrak

Pencatatan pernikahan masih dianggap sebagaian masyarakat sebagai kegiatan hukum yang tidak begitu penting. Hal ini disebabkan anggapan tentang pernikahan yang terpenting sah secara agama demi melindungi diri dari hawa nafsu. Namun, pernikahan bukan hanya tentang hubungan pasangan tetapi hubungan orang tua dan anak, hubungan hukum dan anak. Urgensi pencatatan nikah dapat dilihat dari pemberlakuan hukum pencatatan nikah di setiap negara muslim di dunia. Kedudukan hukum di setiap negara berbeda-beda, ada yang mengatur secara ringan dan ada juga dengan sanksi tegas. Peneliti pada karya tulis ini akan mengulas beberapa perspektif tentang eksistensi pencatatan pernikahan dan hubungan sebab akibat yang timbul dari pernikahan sirri atau pernikahan yang tidak dicatatkan. Penelitian ini menggunakan metode penelitian yuridis normatif, yaitu menelaah pemberlakuan hukum atau peraturan dari berbagai perspektif untuk menemukan sebuah kesimpulan tepat.

Kata Kunci: Pendaftaran Perkawinan, Muslim Lainnya 


\section{INTRODUCTION}

Marriage is a strict family relationship with long-term goal. In this present day, marital registration certainly becomes an authentic evidence couple need to have. It is related to the fact that people's thoughts in past and present are different. Therefore, marital registration becomes an option to make a legal marriage powered by law.

Nowadays, the number of Muslim increased. It is not the same as what happened in the era of Rasulullah and his companions. Even the evidence of a marriage only by holding walimah (wedding banquet) was no problem at that time. Now, walimah is not potent evidence that wife and child take the rights they should have. If misappropriation in household happens, the state can do something using the evidence.

According to syariat (Islamic rules), every muamalah (social interaction) that has great risks, it is important to make akad (a contract) with written evidence and witness. It can be seen in Q.S. al-Baqarah verse 282. Thus, marriage is a long-term team-work activity and has great risks as the other muamalah (social interaction activity does. Marriage is more important, so it should have evidence like marital registration. Before comprehending the urgency of marriage certificate, it is important to know about review of syariat on marital registration and its implementation in Islamic countries over the world.

\section{RESEARCH METHOD}

This research used juridical normative method which this research focused on rule, law, or constitution related to the problem. Then, every rule or law was analyzed $^{1}$ into various perspectives. The research described rule or law of marital registration implemented in Islamic countries to be studied in various perspectives. This research used library study that is gathering books related to rule of marital registration as references. Based on the method, the result hopefully gets proper findings of the urgency of marital registration.

\footnotetext{
${ }^{1}$ Soekanto and Sri Mamudji, Penelitian Hukum Normatif (Suatu Tinjauan Singkat), (Jakarta: Rajawali Press, 2001), p. 13-14.
} 


\section{RESULT AND DISCUSSION}

\section{Marital Registration in Indonesia}

UU No. 1 in the year of 1974 about constitution of marriages. Marriage means a relationship between a man and a woman physically and mentally to live together forever with happiness. ${ }^{2}$ The relationship shows that marriage is an important action to be prepared in implementing or protecting law. Marriage law in Indonesia tells about legal marriage that is held based on religion and faith', which in syariat Islam the requirements of marriage consist of basis and some requirements without stating the marital registration explicitly. Moreover, article in constitution of marriage defines that marriage of every Indonesian person including Muslim should be registered ${ }^{4}$ in Religious Affairs Office (KUA).

Same as rules in constitution of marriage, presidential instruction No. 1 in the year of 1991 about Compilation of Islamic Law also defines that marriage registry or marital registration, and legal power of marriage that is registered. Besides the status of law is obligatory, article 5 of $\mathrm{KHI}$ defines that marital registration as people discipline. ${ }^{5}$ The marital registration is done by an employee of marital registration as it is defined in UU No. 22 in the year of 1946 and UU No. 32 in the year of 1954 .

Not only doing registration as it is defined in article 5, marriage also should be held on the observation of the employee of marital registration, he should watch the marriage of every person (article 6 verse 1 of KHI). Otherwise, the marriage is not holding in the Religious Affairs Office (KUA), the observation can be done by employee of marital registration outside of KUA where the marriage is holding. Furthermore, marriage without registration means does not have legal power (article 6 verse 2 of $\mathrm{KHI}$ ). This means every activity or risk relates to sirri or unregistered and does not become one of state responsibilities. As form of law elasticity, if a marriage has not registered because of something, so the marriage can be registered by way of isbat (article 7 verses 2 and 3 of KHI).

\footnotetext{
${ }^{2}$ Pasal 1 UU No. 1 Tahun 1974: “Perkawinan ialah ikatan lahir bathin antara seorang pria dengan seorang wanita sebagai suami isteri dengan tujuan membentuk keluarga (rumah tangga) yang bahagia dan kekal berdasarkan Ketuhanan Yang Mahaesa".

${ }^{3}$ Pasal 2 [1] UU No. 1 Tahun 1974: "Perkawinan adalah sah apabila dilaksanakan berdasarkan hokum agama dan kepercayaannya itu".

${ }^{4}$ Pasal 2 [1] UU No. 1 Tahun 1974: Pencatatan Perkawinan dilakukan menurut perundangundangan yang berlaku.

${ }^{5}$ Pasal 5 [1] KHI: “Agar terjadi ketertiban bagi perkawinan masyarakat Islam, perkawinan harus dicatatkan".
} 
This can be seen in Compilation of Islamic Law article 7 verses 2, 3, and 4 which regulate isbat.

\section{Marital Registration in Other Islamic Countries}

In this part, the researcher described marital registration system in other Islamic Countries based on its classification, from moderate rules up to strict rules. Implementation of that marital registration system is divided into 3 kinds, they are: ${ }^{6}$

\section{Moderate Rules of Marital Registration}

The Countries that used this kind of marital registration are:

a. Philippines

This country obligates implementation of marital registration as administrative data, but there is no information of the unregistered marriage including the marital status and the consequence of the marital law.

b. Lebanon

This country obligates the employee of marital registration to present and register the marriage, but there is no information of the unregistered marriage including the marital status and the consequence of the marital law.

c. Druze Lebanon

The evidence of marriage must be sent to court so the marital certificate can be released and registered, but there is no information of the unregistered marriage including the marital status and the consequence of the marital law.

d. Algeria

This country allows marriage after getting legalization from authorized employee, but there is no information of the unregistered marriage including the marital status and the consequence of the marital law.

e. Libya

Doing the same as Algeria does, this country states that marriage must be proved with official record (from the court).

\footnotetext{
${ }^{6}$ Khoiruddin Nasution, Hukum Perdata (Keluarga) Islam Indonesia dan Perbandingan Hukum Perkawinan di Dunia Muslim, (Yogyakarta: ACAdeMIA+TAZZAFA, 2009), p. 338-351.
} 


\section{Strict Rules of Marital Registration with Strict Sanctions}

Countries included around this kind:

a. Singapore

This country obligates applying marital registration, if there is a violation it is sentenced to prison for 6 months or $\$ 500$ fine or even both of them.

b. Egypt

Notification of a marriage must be proved with certificate or official evidence (certificate) from the government.

c. Pakistan and Bangladesh

Both countries obligate applying marital registration, for one who breaks against the rule can be sentenced to prison for 3 months or 1000 Rupee fine. For unregistered marriage must be registered soon, there is still a chance.

d. Jordan

This country obligates applying marital registration, for one who breaks against the rule including the employee or the couple can be given a criminal penalty.

e. Syria

This country obligates applying marital registration with one of the requirements is reference letter from doctor that the couple is in good condition without infectious diseases. The marriage must be done in the court. Marriage out of the court can be legalized, but also can be judged first.

f. Tunis

Marriage can only be proved with official record from the government.

g. Iraq

Doing the same as Syria does. Who breaks against the rule, not register the marriage; for who never marries will be sentenced to prison for 6 months, 1 year for maximal punishment and 300-1000 dinar fine. Whoever marries will be sentenced to prison for 5 years.

h. Yemen

For who does unregistered marriage will be sentenced to prison. 


\section{Strict Rules of Marital Registration without Strict Sanctions}

The Countries are:

a) Malaysia

Marital registration is done in 7 days after marital contract. The function of marital registration is only to fulfill the administrative requirements, there is no relevance to the valid requirement of marriage.

b) Iran

This country determines that marriage must be registered, if not so, it must be a violation.

c) Marocco

This country requires 2 signs of notaries, the original record is sent to the court and copy of the record is sent to the civil registration office. Original record is given to the wife while the copy one is given to the husband. Otherwise, there is no sanction on marriage which does not follow the procedure.

\section{An Analysis of Nash provisions about marital registration Dalil Al-Quran and Hadits}

Al-Quran vesrses and Hadits related to marital registration are:

\section{Al-Quran}

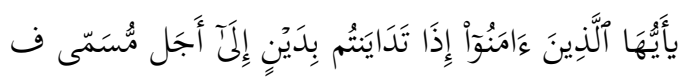

Meaning: O ye who believe! When ye contract a debt for a fixed term, record it in writing. (Al-Baqarah (2) : 282).

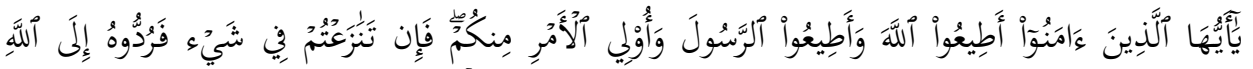

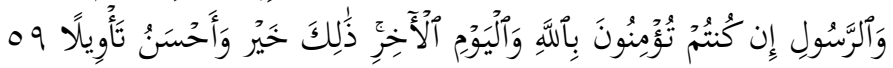

Meaning: O ye who believe! Obey Allah, and obey the messenger and those of you who are in authority; and if ye have a dispute concerning any matter, refer it to Allah and the messenger if ye are (in truth) believers in Allah and the Last Day. That is better and more seemly in the end. (QS. Al-Nisa ayat 59).

\section{Al-Hadits}

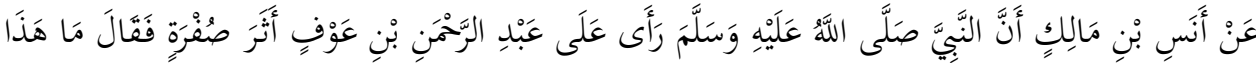

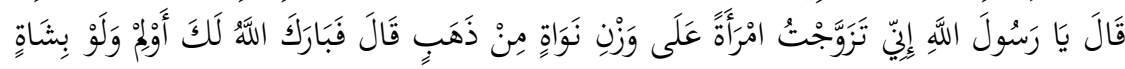


Meaning: Anas bin Malik narrated that the Messenger of Allah SAW saw Abdurrahman bin Auf with traces of saffron on his clothes. He thereupon asked him, "what is that?" Abdurrahman answered, "I married an Ansari woman for a Nawat (five Dirhams) of gold the Messenger of Allah SAW said to him "May Allah bless you. Make a Walimah (wedding banquet) even with only one sheep". (Muttafaq 'alaih dan lafazhnya menurut Muslim). (HR. Muslim No. 2556). ${ }^{7}$

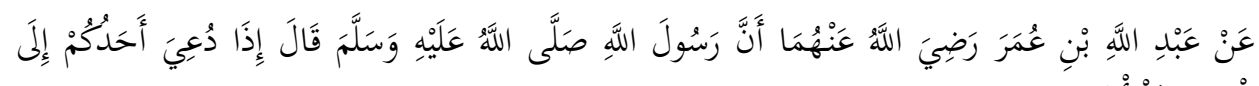

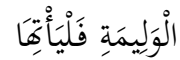

Means: Abdullah bin Umar radliallahu 'anhuma, narrated that the messenger of Allah SWT said "when one of you is invited to a walimah, he should accept the invitation." (Muttafaq 'alaih, HR. Bukhari No. 4775). ${ }^{8}$

\section{Nash Content}

Al-Baqarah verse 282 states about muamalah activity, if the activity does not do cash, it means it does not complete. It needs to make the written evidence and witnesses are faced by two devout people and two non-Muslims that can be reliable if do not find Muslims. ${ }^{9}$ As a figuration term, debts and receivables or the activity in implicit needs to have written

7 Ibnu Hajar al-Asqalani, Bulughul Maram dan Dalil-Dalil Hukum, (Jakarta: Gema Insni, 2013), p. 458.

${ }^{8}$ Ibnu Hajar al-Asqalani, Bulughul Maram...., p. 458.

${ }^{9}$ QS. Al-Baqarah ayat 282: “Hai orang-orang yang beriman, apabila kamu bermu'amalah tidak secara tunai untuk waktu yang ditentukan, hendaklah kamu menuliskannya. Dan hendaklah seorang penulis di antara kamu menuliskannya dengan benar. Dan janganlah penulis enggan menuliskannya sebagaimana Allah mengajarkannya, meka hendaklah ia menulis, dan hendaklah orang yang berhutang itu mengimlakkan (apa yang akan ditulis itu), dan hendaklah ia bertakwa kepada Allah Tuhannya, dan janganlah ia mengurangi sedikitpun daripada hutangnya. Jika yang berhutang itu orang yang lemah akalnya atau lemah (keadaannya) atau dia sendiri tidak mampu mengimlakkan, maka hendaklah walinya mengimlakkan dengan jujur. Dan persaksikanlah dengan dua orang saksi dari orang-orang lelaki (di antaramu). Jika tak ada dua oang lelaki, maka (boleh) seorang lelaki dan dua orang perempuan dari saksi-saksi yang kamu ridhai, supaya jika seorang lupa maka yang seorang mengingatkannya. Janganlah saksi-saksi itu enggan (memberi keterangan) apabila mereka dipanggil; dan janganlah kamu jemu menulis hutang itu, baik kecil maupun besar sampai batas waktu membayarnya. Yang demikian itu, lebih adil di sisi Allah dan lebih menguatkan persaksian dan lebih dekat kepada tidak (menimbulkan) keraguanmu. (Tulislah mu'amalahmu itu), kecuali jika mu'amalah itu perdagangan tunai yang kamu jalankan di antara kamu, maka tidak ada dosa bagi kamu, (jika) kamu tidak menulisnya. Dan persaksikanlah apabila kamu berjual beli; dan janganlah penulis dan saksi saling sulit menyulitkan. Jika kamu lakukan (yang demikian), maka sesungguhnya hal itu adalah suatu kefasikan pada dirimu. Dan bertakwalah kepada Allah; Allah mengajarmu; dan Allah Maha Mengetahui segala sesuatu". 
evidence, however marriage has higher level than muamalah activity so it is the most important to make written evidence. This verse is used as a source of decision of marital registration.

Basically, in Syariat, how much debts of the people have even though it is not in written form just orally it means legal while it is in Islamic rules and requisite. ${ }^{10}$ So, the debts must be paid. There are some part of these Islamic rules, they are: debtors, the lenders, things that lends and ijab and qabul, ${ }^{11}$ but the transaction of debt or other muamalah without written evidence will be difficult to demand for responsible, because orally it is not enough as an evidence. Similarity in marriage, marriage is legal with covenant of marriage and rules based on the article 2 verse 1 UUP, but marriage without written evidence will be difficult to ask responsible if in the future one of the couple do something wrong. ${ }^{12}$

Wahbah Zuhaili states in her book al - Figh al - Islâmî wa Adillatuh, fikih muamalah is the law organize of the relationship of human include the world generally and every covenant of marriage in muamalah activity. Clearly, Wahbah Zuhaili includes marriage covenant to one of muamalah activity in fikih muamalah deeply. ${ }^{13}$

Qs. Al-Nisa: 59 is a commend to obey the Ulil Amri, it is also used as a source of registration rule of law in a country. Ulil Amri has different meaning, it caused the different argument of Ulama to understand this verse. Some of them translate it as leaders/government. And also some of them state they are Ulama, the last, the other hand states Ulil Amri as vise of society in community. ${ }^{14}$ Based on all of the definitions, it can be concluded Ulil Amri is someone and a community that is given legally authority to make a policy for society. This policy must obey for social control. Quraish Shihab states during policy, decision or rule that is given by government for society safety without violating the rule, and must

${ }^{10}$ Chairuman Pasaribu dan Suharwadi K. Lubis, Hukum Perjanjian dalam Islam, (Jakarta: Sinar Grafika, 1994), p.136.

${ }^{11}$ Chairuman Pasaribu dan Suharwadi K. Lubis, Hukum Perjanjian.., p 136.

12 Pasal 7 [1] KHI: "Pernikahan hanya bisa dibuktikan dengan akta nikah yang dibuat oleh Pegawai Pencatat Nikah".

${ }^{13}$ Wahbah al-Zuhayli, al-Figh al-Islâmî wa Adillatuh, Vol. 1, (Damaskus: Dar Al-Fikr, 2004), p. 33.

${ }^{14}$ M. Quraish Shihab, Tafsir Al-Misbah, Vol. 2, (Tangerang: Lentera Hati, 2006), p. 484. 
obey Allah and His Messenger. But if there is a conflict, it should return to Al-Quran and Hadits. ${ }^{15}$

The content of Hadits HR. Muslim Number. 2556 HR. Bukhari Number. 4775 is recommendation to do walimah in wedding banquet and attend the wedding invitation. Walimah intends to share the happiness and also to tell and announce that there is a big event a wedding between a man and a woman. Walimah also shows the thanksgiving to Allah SWT. From this event there is a big evidence that has happened a wedding with a wedding certificate that has a power of law.

\section{The Impact of Unregistered Marriage Based on the Constitutional Court Ruling Number 46/PUU-VIII/2010}

The unregistered marriage is also called as Sirri marriage which according to law is a marriage that has not legal power. The impact of this marriage is very much, especially before getting Constitutional Court Riling number 46/PUU-VIII/2010. Stated in article 2 verse 2 UU No. 1 in 1974 that marriage must be registered clearly. Additionally, in article 43 verses 1 in law point of view that children of this marriage is an extramarital child who only has a civil relationship with the mother and her mother's family. ${ }^{16}$ It means the wife is not considered as a wife by the law state because that marriage is not considered. Not having a civil relationship means not having a biological relationship with the father. In the other hand, if the husband does not do the duty or ignore the duty, the wife cannot involve the state law to protect her rights as a wife and the children rights of her marriage.

Marital status is not registered as a marriage that has no legal force can be seen in the decision of the Constitutional Court Riling number 46/PUU-VIII/2010. ${ }^{17}$ This decision arises on the demand of one of petitioner for the judicial review of article rights to Constitutional Court. The petitioner's name is Ibu $\mathrm{Hj}$. Aisyah Mochtar or Machica binti $\mathrm{H}$.

${ }^{15}$ M. Quraish Shihab, Tafsir Al-Misbah., p. 485

16 Pasal 43 [1] UU No. 1 Tahun 1974 pra Putusan Mahkamah Konstitusi: “Anak yang lahir di luar perkawinan hanya mempunyai hubungan perdata dengan ibu dan keluarga ibunya".

${ }^{17}$ Nur Azizah. (2018). Putusan MK No. 46/2010 tentang Hubungan Keperdataan antara Anak Luar Nikah dan Ayah Biologis (Analisis dalam Persepktif Hukum Islam, Hukum Positif, UIDHR, dan UDHR). FITRAH Jurnal Kajian Ilmu-Ilmu Keislaman, 04(2). 16-17. 
Mochtar Ibrahim. The petitioner demands article 2 verses 2 of UUP and article 43 verses 1 above. The Demanding of this article purposes getting her rights as a wife, law recognition of her marriage status, and the status of her children's rights. But the result of Constitutional Court's decision show that the marriage of the petitioner is still not considered legal by the law, so that the content of the verdict is only to grant revision of article 43 verse 1 of the UUP: "the children born of extramarital have a civil relationship with the mother, mother's family and father's family that can be known by science and technology and other evidence as a father". Even though the children of extramarital can be related to biological relationship with the father, but the decision of this article very strike the child psychology. How is possible the child of legal marriage based on religion is called as "the child of extramarital" which the same position with child of illegal relationship, which is extramarital. The children of Sirri marriage do not get his rights, also must be documented biological evidence. These things have great potential to disrupt a child's psychology.

Considering plenty of bad impacts of unregistered marriage so should be better the couple will get married do not act selfishly. Marriage should consider the future of the offspring and the future of marriage, so the couple should register their marriage, not only for each right but to maintain children rights in the law.

\section{CONCLUSION}

There are differences in law status and law power of registration in every Muslim country in the world including Indonesia and other Southeast Asian countries. This categorizes it as obligatory civil action that causes approved, which is compulsory but not so binding, and there are also not firm and not so clear due to the law and even the law status. But as an agreement, that the marital registration is not be an indicator of legal or not a covenant of marriage, however it refers to lack of law power for couples who do not do registration, because law action only applies to law actions based on authentic evidence.

In Prophet and companions' era the authentic evidence of marriage was sufficient by witnesses of the marriage, but that evidence is not applied in this modern era. The level of society law awareness is also 
declining. So, the act of marital registration is very important to protect the rights of each part involved in the marriage. Addition, Islam region has spread throughout the world, in Indonesia has been very broad, how is it possible to bring witnesses to every place if marriage proof is needed.

The marital registration rules in Muslim countries do not clash with the purpose of Nash Al-Quran and Hadits, even the country has done the best for its citizens in order to protect every society. By considering all the bad things that arise couple, offspring, and orderliness country if the marriage does not run legally, or does not registered, then the society should obey the rules that apply in Indonesia about marital registration duty. Especially in this IPTEK's era, everything must have authentic evidence not just submit to system of mutual trust. 


\section{REFERENCES}

Abdurrahmana al-Jaziri, Kitab al-Fiqh `ala al-Maazahib al-Arba`ah, Vol. II, Dar al-Ihya` al-Turasy al-`Arabi, t.p, 1986.

Ahmad Rafiq, Hukum Islam di Indonesia, Jakarata: Raja Wali Press, 1998.

Ahmad Rofiq, Hukum Perdata Islam di Indonesia, Jakarta: PT. RajaGrafindo Persada, 2013.

Al-Malibariy, Fath al-Mu'zin. Terj., Aliy As`ad, Fath Mu`in , Yogyakarta: Menara Kudus, 1979.

Arso Sosro Atmodjo dan Wasit Aulawi, Hukum Perkawinan di Indonesia, Jakarta: Bulan Bintang, 1981.

Al-Asqalani, Ibnu Hajar. Bulughul Maram dan Dalil-Dalil Hukum, (Jakarta: Gema Insni, 2013).

Al-Zuhayli, Wahbah. al-Fiqh al-Islâmî wa Adillatuh, Vol. 1, (Damaskus: Dar AlFikr, 2004).

Azizah, Nur. (2018). Putusan MK No. 46/2010 tentang Hubungan Keperdataan antara Anak Luar Nikah dan Ayah Biologis (Analisis dalam Persepktif Hukum Islam, Hukum Positif, UIDHR, dan UDHR). FITRAH Jurnal Kajian Ilmu-Ilmu Keislaman, 04(2).

Instruksi Presiden Nomor 1 Tahun 1991 tentang Kompilasi Hukum Islam

Nasution, Khoiruddin, Hukum Perdata (Keluarga) Islam Indonesia dan Perbandingan Hukum Perkawinan di Dunia Muslim, (Yogyakarta: ACAdeMIA+TAZZAFA, 2009).

Pasaribu, Chairuman, Suharwadi K. Lubis. Hukum Perjanjian dalam Islam, (Jakarta: Sinar Grafika, 1994).

Shihab, M. Quraish Shihab. Tafsir Al-Misbah, Vol. 2, (Tangerang: Lentera Hati, 2006).

Soekanto, Sri Mamudji, Penelitian Hukum Normatif (Suatu Tinjauan Singkat), (Jakarta: RajawaliPress, 2001).

Undang-Undang No. 1 Tahun 1974 tentang Undang-Undang Perkawinan 